\title{
Participation in online activation (\#) campaigns: A look at the drivers in an African setting
}

\author{
Abena A. Yeboah-Banin \\ Senior Lecturer \\ Department of Communication Studies \\ University of Ghana, Legon, Ghana \\ E-mail: ayeboah-banin@ug.edu.gh; animwaayeboah@yahoo.com
}

\author{
Marian Tsegah \\ Lecturer \\ Central University, Miotso, Accra \\ E-mail: mtsegah@central.edu.gh; m_tsegah@yahoo.com
}

Submitted: April 4, 2018/ Accepted: October 15, 2018 / Published: December 3, 2018

\begin{abstract}
Online brand activation is in vogue and has been used by several brand giants (e.g. Apple, Adidas, etc.) to create viral campaigns that invite consumers to join brand-initiated conversations. The opportunities therein for brand visibility and customer engagement are immense. However, to leverage it, brand communicators must first understand the characteristics of persons most likely to participate in it and target them, a question that is yet to be addressed in the budding literature on the subject. For brand communicators, particularly in developing economies such as Ghana where low internet penetration levels and high associated costs may hinder participation, this is a critical gap in their quest to justify the relevance of online activations to boost brand visibility and customer engagement. This study sought to address this gap by testing a model of the drivers of participation in online activations using a consumer survey $(\mathrm{N}=278)$, set in a recent online activation campaign in Ghana. The findings suggest that persons who trust the activated brand would be inclined to participate in it, suggesting the need for brand communicators to first work on building trust. The study also finds that individuals who are susceptible to interpersonal influence are less likely to participate in such activations. Possible explanations for this are explored in the study along with their implications.
\end{abstract}

Keywords: online activations, social media, brand communication, Ghana, customer engagement 


\section{Introduction}

In big consumer markets such as the USA and the UK, online brand activations have joined the repertoire of strategies used by brand communicators to engage audiences and build visibility for brands (Van Noort, Antheunis \& Van Reijmersdal, 2012). Contemporary communication campaigns by brands typically include a web-based activation element where targets are invited to join the 'conversation', and share their own experiences (Jansen, Sobel \& Cook, 2011). We define online brand activations as invitations to brand lovers, consumers, and followers to join online brand-related conversations by sharing their brand experiences (e.g. posts, selfies, comments etc.), and associating with brands online. Artefacts of online activations may take various forms including brand selfies, posting of comments, and following brand-generated conversations as well as joining hashtag conversations (the use of the symbol '\#' to precede words/phrases/sentences on social media to identify and connect messages on a specific topic).

Arising out of brands' need to leverage more touch-points with increasingly fragmented audiences (Christopher, 1996), online activations help brands to generate discourses that coalesce into online tribes of engaged customers (Cova \& Pace, 2006). Herein also lies the opportunity for earned media and viral visibility. By asking targets to post brand selfies, join ongoing 'hashtag' conversations, or initiate their own brand stories, online activations also enhance evangelism opportunities (Van Noort, Antheunis \& Van Reijmersdal, 2012).

Though not an old strategy, online activations are already evolving into a profitable industry as social media platforms recognize their power and begin to charge for mounting them. For instance, a 2015 Financial Times report quoted Snapchat as charging \$750,000 from brands seeking to activate user-generated selfies on the platform (Financial Times, 2015). Several brands have launched online activations including Apple's Beats Electronics' 2014 \#SOLOSELFIE(asking fans to promote the Solo2 headphones) (Willens, 2014) and the World Wildlife Fund's \#LastSelfie (inviting 
Snapchat users to take a picture of its endangered species adverts and Snapchat it to their friends) (Cision, PR Newswire, 2014).

While online activations are common in large economies and are attracting scholarly attention (Presi, Maehle \& Kleppe, 2016; Sung et al., 2016; Van Noort, Antheunis \& Van Reijmersdal,2012), very little is understood about them in developing countries where many internet-based phenomena remain a novelty. Yet, with such benefits, and given the tendency for developing markets to replicate best practices from bigger markets (Spencer, 2008), it is no surprise that online activations are gaining attraction in developing countries such as Ghana. For instance, in December 2016, CloseUp launched the \#BlueChristmas selfie campaign asking Ghanaian consumers to post pictures of themselves with CloseUp Blue, online (CloseUp Ghana, 2017). MTN, in early 2017, also launched a campaign commemorating Ghana's $60^{\text {th }}$ independence anniversary requesting Ghanaians to post their uniquely Ghanaian experiences on social media using \#ItsAGhanaThing to join the conversation (MTN Ghana, 2017). To combat a nationwide illegal mining ("Galamsey") menace, Citi FM (an Accra FM station) and later, the Media Coalition Against Galamsey also launched an online activation asking Ghanaians to share and spread stories of the dangers of 'Galamsey' using the \#StopGalamseyNow hashtag (Ghana Web, 2017).

Clearly, online activations are gaining popularity in Ghana. Yet conditions within developing countries may challenge their uptake by audiences. As established in existing literature, differences across markets may interfere with cross-context replication of marketing (communication) practices (Sheth, 2011). For instance, low internet penetration levels (World Bank, 2014) coupled with high costs (Opoku \& Kuranchie, 2015) mean consumers may be unable to join in such purely web-based campaigns. Indeed, given the high data costs, targets may rather choose other uses for their data rather than use it to 'propagate' a brand's cause. Thus, it appears that it takes a certain kind of person to go beyond such conditions

\footnotetext{
1 A Ghanaian term derived from the expression "gather them and sell". In essence, it means illegal small-scale gold mining.
} 
and participate in online activations. To leverage the benefits, therefore, brand communicators must understand the unique domain in which they operate (Labrecque, 2014).

With current scholarship focusing on brand-target conversations via websites (Opoku, Abratt \& Pitt 2006; Wang, 2006), brand communities (Brodie et al., 2013) and social media pages (Chu and Kim 2011), online activation campaigns remain under-studied. The closest attempt at exploring the issue, perhaps, comes from recent scholarship on brand selfie activations (a form of online activations) (see Kedzior, Allen \& Schroeder, 2016; Presi et al., 2016). Yet these remain largely conceptual. Thus, online activations have yet to be engaged in the empirical literature to bring clarity to their scope, drivers, consequences and boundaries. Importantly, this also means context-based differences that attend online activations, including conditions existing in developing countries remain under-explored.

To contribute to bringing clarity to some of the issues raised, this study explores online activation campaigns using consumer data from Ghana. Starting off with the question 'who is the ideal target of an online activation campaign?', the study attempts to explain participation in online activation campaigns as a form of customer engagement behaviour demonstrated towards brands. It then tests a conceptual model that argues brand identification, brand trust, market mavenism (individuals' drive to influence the marketdirected behaviours of members within their online networks [Faick \&Price, 1987]) and individual susceptibility to influence as the main drivers of participation in online activations. By so doing, the study lays the foundation for recognizing the online activation phenomenon to pave the way for scholarly engagement with it. Given their rising popularity across the globe, online activations promise to change the face of marketing communications, requiring the scholarly fraternity to generate understanding of the phenomenon to guide practitioners.

To our knowledge, this study is among the first to examine the empirics behind online activations in Ghana. This sets the tone for 
understanding how to target such campaigns to the right audiences, enabling practitioners to manipulate and leverage the benefits of online activations. Our attempt to explain participation in online activations from the perspective of customer engagement behaviours also invites scholars to a theoretical lens for understanding the behaviour. Importantly, doing these with data from a developing country enriches the literature with rare evidence.

\section{Background to the study}

The study is set in a recent online activation campaign in Ghana. At the peak of campaigning for Ghana's 2016 general elections, a photo of the opposition candidate (now president) Nana Addo Dankwa Akufo Addo (hereafter Nana Addo) in which he was drinking Kalyppo, a local fruit juice brand mainly targeting children, begun to circulate on social media. Given his age (72 years), political opponents sought to use it to suggest his general inability to cope with the energy demands of campaigning, and for the presidency. To counter the potential negative effect on the Nana Addo brand, his New Patriotic Party (NPP) launched an online activation campaign encouraging the public to post selfies of themselves and Kalyppo as a show of solidarity. This instigated the highly popular \#KalyppoChallenge campaign across various social media platforms (Facebook, Twitter, Instagram, YouTube) in which people posted their own selfies or shared, commented on and liked those of others. The typical \#KalyppoChallenge showed participants using Kalyppo in often funny scenarios accompanied by the KalyppoChallenge hashtag (\#).

\section{Online brand activations: A consumer brand engagement perspective}

When brand communicators invite audiences to join activations and tell their stories, spins and interpretations of brands (Mancuso \& Stuth, 2014), they require latter's response to give life to the campaign. Thus, the audiences determine whether campaigns would gather momentum and generate the visibility targeted by brand communicators. The response may manifest in varied 
forms including creating and posting content, 'sharing' and liking others posts, etc. While this suggests a multi-dimensional tone to the participation in online activation construct, our core interest lies in the consumer engagement underpinnings of the behaviour, irrespective of the form in which it evidences itself. We view the underlying ingredient to achieving success in such activations as resting with the individual target member's participatory action which, according to Dijkmans et al (2015), is indicative of involvement and engagement with the brand.

Given that consumers seek to use their social media/online behaviours as a means of self-expression and personal branding (Labrecque, Markos \& Milne, 2011), it appears that participation in such activations is enacted as a form of customer engagement with the brand (Van Varik \& van Oostendorp, 2013). This is corroborated by current conceptualization of online activation artefacts such as brand selfies suggesting close links with personal branding. For instance, Eagar and Dann (2016) argue that consumers post brand selfies to give expression to their inner persons in a quasipersonal branding effort. Similarly, Saltz (2014, p. 3) has argued that individuals' online posts mimic 'letters to the world' about their brand experiences.

These arguments about the self-expression intent of such online behaviours suggest a personal investment in the brand which signals consumer engagement. We view the personal investment underlying such behaviours as a form of engagement behaviour because it means individuals (interacting with brands online) appropriate brands to their lives to the extent where propagating the brand has direct implications for them. According to Hollebeek, Glynn and Brodie (2014, p. 154), consumer brand engagement is 'a consumer's positively valenced brand-related cognitive, emotional and behavioural activity during or related to focal consumer/ brand interactions'. It is a multidimensional construct that includes 'activation' which represents actual engagement behaviours such as effort and time spent interacting with a brand (Hollebeek, Glynn $\&$ Brodie, 2014, p. 154). It encapsulates the varied ways (beyond 
transactional) in which customers demonstrate their interest in brands (Van Doorn et al., 2010).

As a behavioural construct, therefore, engagement's roots lie in the verb 'to engage' which refers to interest beyond the mere liking for something, and manifesting rather as a strong sense of connection and action towards it (Hollebeek, Glynn \& Brodie, 2014). The sense of connection serves a motivational effect to drive individuals towards interactions with the brand and its stakeholders. Engagement behaviours, therefore, draw from personal motivational drivers and target a broad scope of responses that have a brand as the object (Hollebeek, 2011). Customer engagement behaviours can be positive or negative, manifesting as brand choice or switching, helping behaviours, referrals, co-creation and the exercise of voice (both praise and complaint) (Maslowska, Malthouse \& Collinger, 2016).

It is within the voice expression element of the consumer brand engagement construct that we situate participation in online activations. The exercise of voice refers to the choice to communicate individuals' brand experiences and associations in the public domain (Qui et al., 2015). It manifests variously including complaint making, positive or negative (electronic) word of mouth, participation in brand communities and blogging (Van Doorn et al., 2010). Thus, to the extent that participation in online activations takes the form of joining brand-initiated conversations/posting brand-solicited messages, it signals individuals exercising voice (Mancuso \& Stuth, 2014) and demonstrating brand engagement behaviour.

Indeed, scholars have argued that within the specific context of social media, consumer engagement takes on an interactivity essence based on the interactive characteristics of the Web 2.0 medium (Hollebeek, Glynn \& Brodie, 2014). For this reason, the online space and social media in particular present useful avenues for understanding consumer engagement. It becomes reasonable, then, to view customers' interactions with brands online as a means of demonstrating aspects of their engagement with the latter. Even 
negative voice expression demonstrates engagement to the extent that individuals choose to complain and seek remedial action rather than just switch brands. Accordingly, we view participation in online activations as signaling customer engagement by the personal investment roots from which the behaviour is drawn as well as the activation of interaction with the brand.

\section{Research hypotheses}

The foregoing highlights how consumers may appropriate online activations to their own ends signaling the primacy of person-based variables in activating the participation behaviour. Yet few indications exist by way of scholarship. To illuminate this, we identify from the perspective of customer engagement behaviour scholarship, four factors primary to the drive to participate in online activations - market mavenism, brand identification, brand trust and individuals' susceptibility to interpersonal influence. Figure 1 presents a conceptual model proposing these relationships.

\section{Fig. 1: Conceptual model}

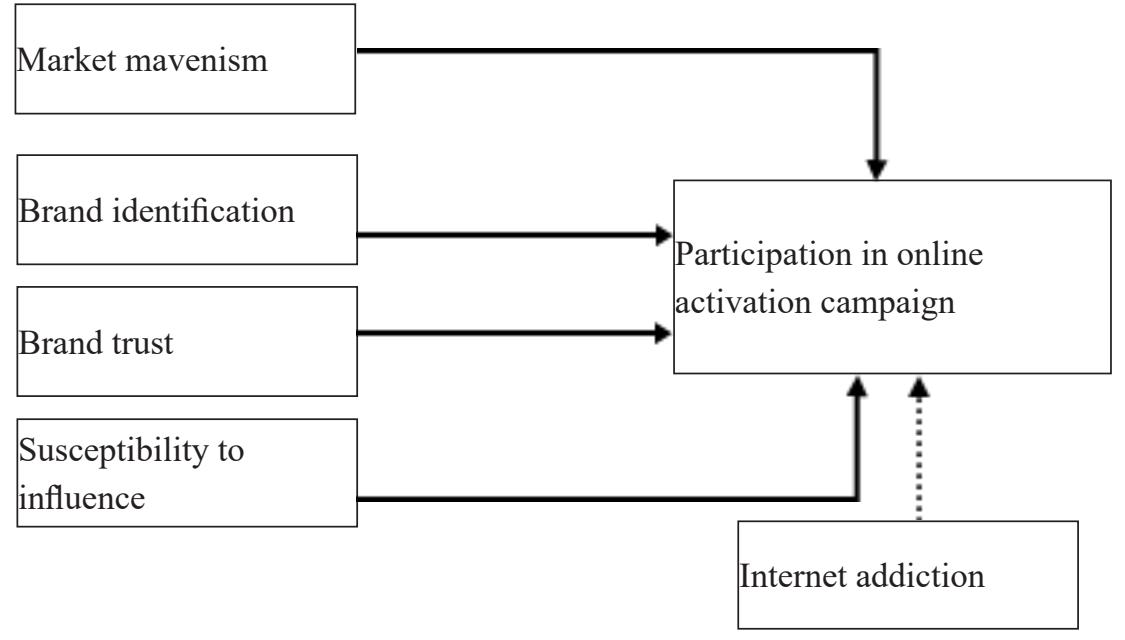

Source: Author-generated conceptual model

First is the individual's quest to influence the market- 
directed behaviours of members within their online networks. Individuals high on this behaviour are market mavens who position themselves as purveyors of market information (Feick \& Price, 1987). Market mavens tend to be highly engaged with the market and seek to acquire and share knowledge about same to project an 'expert' image of themselves (Packard \& Wooten, 2013; SudburyRiley, 2016). This positions mavenism as a form of engagement behaviour given that it can be directed at a particular brand (Feick $\&$ Price, 1987). Because mavens want to be seen to be aware of changes in the market (Lee, Leizerovici \& Zhang, 2015), they may participate in online activations as a means of showing that they are 'on top of' happenings in the market (Sudbury-Riley, 2016).

Mavenism is also strongly linked with extraversion and word of mouth behaviour (Sorokowska et al., 2016), suggesting the self-expressive roots of engagement behaviours (Berger, 2014). To the extent that online posts are 'letters' written to the world (Saltz, 2014), mavens seeking avenues for self-expression may view activations as another forum to enact their expressiveness. This logic is supported by evidence from Islam, Rahman and Hollebeek (2017) that extraversion drives consumers' engagement within online communities. Finally, evidence from Sudbury-Riley (2016) shows that mavenism generates positive attitudes towards advertising for which reason knowing that online activations are part of a brand's advertising efforts should make them well received by mavens. Accordingly, the conceptual model includes the expectation that:

H1: Market mavenism is positively related to participation in online activations.

The second variable expected to drive participation in online activations is the individual's personal identification with a brand (Hollebeek, Glynn \& Brodie,2014). Brand identification is a form of engagement behaviour that stems from an internal evaluation of how well a brand matches one's personal values (Tuškej, Golob \& Podnar, 2013). A resulting positive conclusion means individuals are more willing to associate with the brand in public, 
even to the extent of engaging in brand advocacy (StokburgerSauer, Ratneshwar \& Sen, 2012). We view participation in online activations as an example of such advocacy behaviour arising out of positive identification with a brand. If individuals use the social media space for personal branding (Krämer \& Winter, 2008), then the extent of fit between them and brands should trigger a willingness to associate with the latter in this public sphere.

In other words, persons identifying with a brand so define themselves by it that, joining such activations becomes a means of enacting the association. Accordingly, brand-identified individuals should be more willing to join brand-initiated activations to demonstrate their associations with same. Such reasoning finds support from Ahearne, Bhattacharya and Gruen (2005) who suggest engagement behaviours to demonstrate consumers' identification with a brand to the extent of wanting to publicly associate with and support it. A similar argument has been proffered by Hollebeek (2011) who shows that brand identification underpins customer engagement behaviours. This leads us to the supposition that:

H2: There is a positive relationship between brand identification and participation in online activation campaigns.

We also propose that the extent of individuals' trust in brands is a precursor to their participation in online activations initiated by the latter. This position stems from scholarly suggestions that trust underlies engagement behaviours (Chaudhuri \& Holdbrook, 2001). Because trust is a customer's faith in the brand's ability to fulfill promises (Chaudhuri \& Holdbrook, 2001), its existence presages the customer's willingness to interact with the brand. According to Morgan and Hunt (1994) trust is a core determinant of exchanges between individuals and brands. It involves calculations about a brand's credibility and provides a route to persuasion such that trusted brands are more persuasive in getting customers to interact with them (Kitchen et al., 2014).

Conversely, without trust individuals may not exhibit engagement behaviours such as the exercise of voice involved in participating in online activations. Similarly, where invitations to 
participate in online activations are accompanied by incentives, less trusting customers may fail to believe the offer and subsequently refuse to participate in them (Cheng \& Vassileva, 2006). This leads to the proposition that:

H3: Brand trust is positively related to participation in online activation campaigns

Finally, our model predicts that individuals' susceptibility to interpersonal influence may inhibit their willingness to participate in online activations. Bearden, Netemeyer and Teel (1989) define susceptibility to interpersonal influence as the need to identify with, or enhance one's image in the opinion of significant others via conformist behaviours. Individuals susceptible to influence, therefore, need additional impetus from their social circles to engage in what they perceive to be 'socially approved' behaviours (Wang, $\mathrm{Yu} \& \mathrm{Wei}, 2012)$. Thus, unless the individual is surrounded by significant others whose participation in such activations becomes examples to conform to (or who goad them into such behaviours), the likelihood of such participation dwindles.

However, as has been argued by Van Varik and Van Oostendorp (2013), most online users passively consume information shared in their online (brand) communities. Thus they are unlikely to actively generate attention to received messages by forwarding (Romero et al., 2010). This reduces the odds that susceptible individuals would receive the necessary nudging (from their influencers) to participate in activations. In the absence of this nudging, however, susceptible individuals have little motivation to conform by participating in online activations. For this reason, we expect individuals susceptible to interpersonal influence to not participate in online activations as the needed drive to participate is unlikely to be easily forthcoming (Romero et al., 2010).

H4: Susceptibility to interpersonal influence is negatively related to participation in online activation campaigns.

In order not to be duplicative of existing knowledge, we 
also included internet media addiction as a control variable. As argued by the media system dependency perspective, as individuals become reliant on a medium, they consume it more and may be better influenced by it (Paul, 2015). To that extent, persons addicted to social media, spend a lot of time there looking for activities to occupy their time, thus increasing the chances of their participation. This is corroborated by empirical evidence from Whang, Lee and Chang (2003). For this reason, the conceptual model controlled for the direct relationship between internet addiction and participation in online activations.

\section{Methodology}

\section{Data setting and sampling}

The data for the study was collected from a sample of university students in Ghana over a six-month period in 2017. Three reasons underscored the selection of Ghana as the empirical setting. Ghana enjoys a highly pluralistic media environment in which social network platforms such as Facebook, Twitter, Instagram and WhatsApp are highly popular particularly among the younger demographic (Owusu-Acheaw \& Larson, 2015). Secondly, Ghana has, in recent times, been home to various online based brand activations, including the CloseUp Blue's selfie activation (\#BlueChristmas), MTN's \#GhanaThings campaign and CitiFM's \#StopGalamseyNow campaign. Lastly, it was more convenient to gather the data from the country because we live here and it was easier getting to our sample from our respective institutions.

We employed a series of convenience sampling approaches to collect data from a sample of 288 students in two universities. While convenience sampling is less preferred in studies of this nature, we were constrained to employ it given that we wanted to collect the evidence in the moment while the activation was still ongoing. Unfortunately, this meant that there was no room to afford official bureaucratic procedures for ascertaining student populations and accessing residential lists to use as sampling frames to allow for random sampling. Regarding the choice of universities, we chose 
the University of Ghana (UG) and Central University (CU), given their special positions as the largest public and private universities respectively, in Ghana. For this reason, they gave us access to large numbers of mixed demographic students.

As a caveat, we note that while the brand instigating the activation was the NPP/Nana Addo, most \#KalyppoChallenge posts showcased the Kalyppo drink. Thus, prior to the survey data collection, we sought to ascertain whether it was the Nana Addo brand, rather than Kalyppo, that was instigating participation. We interviewed five participants in the \#KalyppoChallenge who corroborated the view that their participation was in solidarity with the Nana Addo brand. Additionally, a look at the comments generated by the \#KalyppoChallenge posts social media showed that the Nana Addo brand was the main subject of discussion rather than Kalyppo. We also interviewed an official of Aquafresh Ghana, producers of Kalyppo who denied any involvement in instigating the campaign for the benefit of their brand. Accordingly, we concluded that the activation initiated by the Nana Addo camp did indeed have him as the object in the minds of the consuming public.

In each university, sampling begun with the purposive selection of mixed sex residences. In each residential facility, a room was accidentally chosen as a starting point. Following this, we used a skip method by which each adjoining room was skipped in favor of the next. We sampled one person from each room, using a convenience approach. Where a person declined participation, we moved on to the next. Respondents self-administered their surveys. A total of 288 surveys were completed $(\mathrm{UG}=\mathrm{N} 123$; CU = N165). Initial data examination, however, led to the exclusion of 10 responses due to failure to provide responses to the criterion variable (participation). As a result, the study is based on 278 responses.

Descriptive analysis of the data shows that the sample had more females $(58 \%)$ than males $42 \%)$. At least $88 \%$ of the sample were active social media users with use levels ranging 'very often' (55\%) to 'always' (33\%). Given that the data is from a university 
setting, all respondents had had formal education and tended to be studying at the undergraduate level (with a few exceptions studying diploma and post graduate courses). Overall, most of the respondents had, in some way, participated in the activation event within which our data is set (\#KalyppoChallenge). Across four dichotomous items measuring varying forms of participation, we found respondents had participated by liking, commenting on and sharing other people's \#KalyppoChallenge selfies (in descending order). Selfie posts emerged as the least means of participation (See Table 1).

Table 1: Participation formats

\begin{tabular}{|l|l|l|}
\hline \multirow{2}{*}{ Variant of participation } & \multicolumn{2}{|c|}{ Frequencies (\%) } \\
\cline { 2 - 3 } & Yes & No \\
\hline Posted own \#KalyppoChallenge & $32(11.5)$ & $246(88.5)$ \\
\hline $\begin{array}{l}\text { Shared other people's } \\
\text { \#KalyppoChallenge }\end{array}$ & $72(26)$ & $206(74)$ \\
\hline $\begin{array}{l}\text { 'Liked' other people's } \\
\text { \#KalyppoChallenge }\end{array}$ & $114(41)$ & $164(59)$ \\
\hline $\begin{array}{l}\text { Commented on other people's } \\
\text { \#KalyppoChallenge }\end{array}$ & $103(37)$ & $175(63)$ \\
\hline
\end{tabular}

Source: Field data

\section{Measures}

To assure ourselves that the sample was relevant to the study, the instrument began with a question as to how often respondents used social media. The dependent variable, participation in online activation campaign, was a dichotomous variable tapping whether respondents did (not) participate in the \#KalyppoChallenge. We used multi-item measures anchored on five-point Likert scales for all predictors. To assess market mavenism, we used my friends look up to me to provide them with current information; If someone needed information on social media, I could tell them where to look and my friends think of me as a good source of information on brands based on Faick and Price (1987). We measured brand identification, with 
four items adapted from Tuškej, Golob and Podnar (2013): I feel a personal connection to $[X]$; I think the $[X]$ brand helps me become the type of person I want to be; $[X]$ symbolizes the way I want to present myself to others and $[X]$ brand image suits me well. We adapted the measure for brand trust from Chaudhuri and Holbrook (2001) using I consider [X] to be dependable, I consider [X] to be honest, I consider $[X]$ to be reliable and I consider $[X]$ to be sincere.

The measure for susceptibility to influence included three items, drawn from Bearden, Netemeyer and Teel (1989). The items are: it is important that others to like the things I do, I often identify with other people by buying the products they buy, and I achieve a sense of belonging by behaving like other people. Finally, to control for respondents' overall addiction to internet use as a possible confound, we adapted Wang, Lee and Chang's (2003) social media addiction scale thus: I see myself as an internet addict; I cannot go a whole day without using the internet and My participation in social media discussions is a key part of my day.

\section{Measure assessment and validation}

Given that we used data from two university campuses, we assessed the equivalence of measures across samples. We undertook confirmatory factor analysis (CFA) employing the maximum likelihood estimation procedure in LISREL 18.50. We assessed model fit with the traditional chi-square $\left(\chi^{2)}\right.$ test along with accepted fit heuristics (root mean square error of approximation \{RMSEA\}, Normed Fit Index $\{\mathrm{NFI}\}$, Non-Normed Fit Index $\{\mathrm{NNFI}\}$ and Comparative Fit Index $\{\mathrm{CFI}\})$. Results show that our measures demonstrate a similar pattern across samples ensuring that they are invariant across the samples (Model 1: $\{\chi 2 /$ degrees of freedom $=$ 180.47/109, $\mathrm{p}<0.00$; RMSEA $=0.06$; NFI $=0.92$; NNFI $=0.95$; CFI $=0.96\} ;$ Model 2: $\{\chi 2 /$ degrees of freedom $=210.08 / 109, \mathrm{p}<$ 0.00 ; RMSEA $=0.07$; NFI $=0.91$; NNFI $=0.94 ; \mathrm{CFI}=0.95\}$ ). Following this assurance, we combined the samples and undertook an overall analogous CFA. Results show that the model replicates the data well $(\{\chi 2 /$ degrees of freedom $=172.12 / 109, \mathrm{p}<0.00$; $\mathrm{RMSEA}=0.05 ; \mathrm{NFI}=0.95 ; \mathrm{NNFI}=0.97$; Comparative Fit Index 
$(\mathrm{CFI})=0.98)$.

We assessed convergent validity and found all item loadings to be significant at $1 \%$ level. Loadings ranged between 0.56 and 0.97 (see Appendix 1). Composite reliability (CR) for all constructs exceeded the 0.60 minimum with the lowest being 0.76 and the maximum being 0.96 . To ensure discriminant validity, construct inter-correlations, variance extracted for each construct (AVE), and the highest shared variance (HSV) between construct pairs were examined. Correlations among the constructs were acceptable (Zeriti, Robson, Spyropoulou, \& Leonidou, 2014). AVEs were acceptable at both minimum (.53) and maximum (.88) levels. A closer look by comparing squared correlations (HSVs) and AVEs found the latter to be larger than the former across board (See Table 2 ). Altogether, these findings assure that the constructs in the model display adequate validity and reliability.

Table 2: Construct validity and reliability

\begin{tabular}{|c|c|c|c|c|c|c|c|c|c|}
\hline \multicolumn{2}{|c|}{ Constructs } & \multirow{2}{*}{$\begin{array}{c}\text { Composite } \\
\text { reliability }\end{array}$} & \multirow{2}{*}{$\begin{array}{c}\text { Average } \\
\text { Variance } \\
\text { extracted }\end{array}$} & \multirow{2}{*}{$\begin{array}{c}1 \\
\\
-\end{array}$} & \multirow{2}{*}{$\begin{array}{c}2 \\
\\
\\
.07\end{array}$} & \multirow{2}{*}{$\begin{array}{c}3 \\
\\
\\
.01\end{array}$} & \multirow{2}{*}{$\begin{array}{c}4 \\
\\
.00 \\
\end{array}$} & \multirow{2}{*}{$\begin{array}{c}5 \\
\\
\\
.10\end{array}$} & \multirow{2}{*}{$\begin{array}{r}6 \\
\\
.12 \\
\end{array}$} \\
\hline 1 & $\begin{array}{l}\text { Participation } \\
\text { in activation }\end{array}$ & & & & & & & & \\
\hline 2 & Market maven & .88 & .75 & $-.28^{* *}$ & .89 & .01 & .00 & .08 & .16 \\
\hline 3 & $\begin{array}{l}\text { Brand } \\
\text { identification }\end{array}$ & .93 & .79 & $-.12^{*}$ & $.14^{*}$ & .94 & .23 & .06 &.-1 \\
\hline 4 & Brand trust & .96 & .88 & .07 & -.05 & $.48^{* *}$ & .96 & .00 & .00 \\
\hline 5 & $\begin{array}{l}\text { Susceptibility } \\
\text { to influence }\end{array}$ & .76 & .53 & $-.32^{* *}$ & $.29^{* *}$ & $.26^{* *}$ & .08 & .75 & .12 \\
\hline 6 & $\begin{array}{l}\text { Internet } \\
\text { addiction }\end{array}$ & .85 & .68 & $-.35^{* *}$ & $.41^{* * *}$ & $.13^{*}$ & .03 & $.35^{* *}$ & .85 \\
\hline \multicolumn{10}{|c|}{$\begin{array}{l}\text { *Correlation significant at the } 0.05 \text { level (2-tailed); **Correlations significant at the } 0.01 \text { level } \\
\text { (2-tailed); alpha values for multi-item constructs } \\
\text { are reported on the diagonal, in bold font; Highest shared variance (Squared Correlations) above } \\
\text { diagonal. }\end{array}$} \\
\hline
\end{tabular}

Source: Field data 


\section{Structural model estimation}

Prior to estimating the structural model, the means of the construct indicants were taken to create composite indicants of latent constructs (Katsikeas, Skarmeas \& Bello, 2009). Following this, and considering that our criterion variable is a dichotomous non-metric one, we proceeded to estimate a logistic regression model. The logistic regression is a popular predictive tool for modeling consumer behaviour and tendencies (e.g. who is likely to not/buy a new product). It stands superior to others (e.g. OLS and discriminant function analysis) given that it is more robust to violations of normality assumptions and easily interpretable (Akinci et al.2007).

We, therefore, felt assured to use the procedure to examine the extent to which the hypothesized variables contribute to a statistically significant separation between online activation campaign participants and non-participants. We defined participation here to mean persons posting their self-generated \#KalyppoChallenge selfies during the campaign. The model was statistically significant $(\mathrm{X} 2=6.10, d f=8 ; \mathrm{p}=.64)$ and correctly classified $91 \%$ of the cases, explaining $39 \%$ of variation in the participation variable (Nagelkerke $R 2$ ).

\section{Findings}

Regarding the hypothesized paths, we argued, in H1, that market mavenism is a positive grouping variable for predicting a person's participation in an online activation campaign. Table 3 shows that this is not supported as the parameter estimate for this hypothesis is not statistically significant $(\beta=-.359, \mathrm{p}>.05)$. Thus, the study finds that market mavens are no more likely than non-mavens to participate in online activations making the variable inconsequential to the incidence or otherwise of participation. 
Table 3: Results of hypotheses tests

\begin{tabular}{|c|c|c|c|c|}
\hline Predictors & B & Sig. & $\operatorname{Exp}(B)$ & Results \\
\hline Market mavenism & -.359 & .129 & .699 & $\begin{array}{c}\text { Not } \\
\text { supported }\end{array}$ \\
\hline Brand identification & -.491 & .032 & .612 & $\begin{array}{c}\text { Not } \\
\text { supported" }\end{array}$ \\
\hline Brand trust & .717 & .004 & 2.047 & Supported \\
\hline $\begin{array}{l}\text { Susceptibility to } \\
\text { influence }\end{array}$ & -.716 & .018 & .489 & Supported \\
\hline $\begin{array}{l}\text { Internet addiction } \\
\text { (control) }\end{array}$ & -1.193 & .000 & .303 & --- \\
\hline Constant & 8.288 & .000 & 3977.112 & --- \\
\hline \multicolumn{5}{|c|}{$\begin{array}{l}\text { Predicted variable: Participation in online activation campaign } \\
\text { Model statistics: Homer and Lemeshow goodness of fit } \\
\text { chi Square } \mathrm{X}^{2}=6.10, \mathrm{df}=8 ; \mathrm{p}=.64 ; \text { Nagelkerke } \mathrm{R}^{2} \text { (variance explained) }=39 \% \text {; } \\
\text { Correctly classified cases: } 91 \% \\
\text { *Relationship is significant as predicted but in the opposite direction }\end{array}$} \\
\hline
\end{tabular}

Source: Field data

The second hypothesis specifies the relationship between brand identification and participation in online activation campaigns to be positive and significant. This is also not replicated in the data as it only partially vindicates our assumptions $(\beta=-.491, \mathrm{p}<.05)$. Whereas identification with the brand strongly predicts who will participate (as suggested by our hypothesis), the negative direction of effect contrasts our expectation. Thus, we conclude that $\mathrm{H} 2$ fails to find support in the data. Indeed, brand-identified persons are $61 \%$ times less likely to participate in online activations by the brand.

The data support the expectation, in $\mathrm{H} 3$, that the extent of trust individuals have in a brand strongly predicts their participation in an online activation campaign initiated by the brand $(\beta=.717, \mathrm{p}$ $<.05$ ). As expected, the study finds that the more individuals trust a brand, the more likely they are to participate in online activations initiated by the brand. Indeed, brand trusting individuals are over 200 per cent times more likely than not to participate in such activations. Finally, the data also replicate the logic behind $\mathrm{H} 4$ 
suggesting that individuals susceptible to influence would fail to participate in online activation campaigns $(\beta=-.716, p<.05)$. We find that individuals who are susceptible to interpersonal influence are nearly $50 \%$ less likely than their less susceptible colleagues to participate in online activations (See Figure 2).

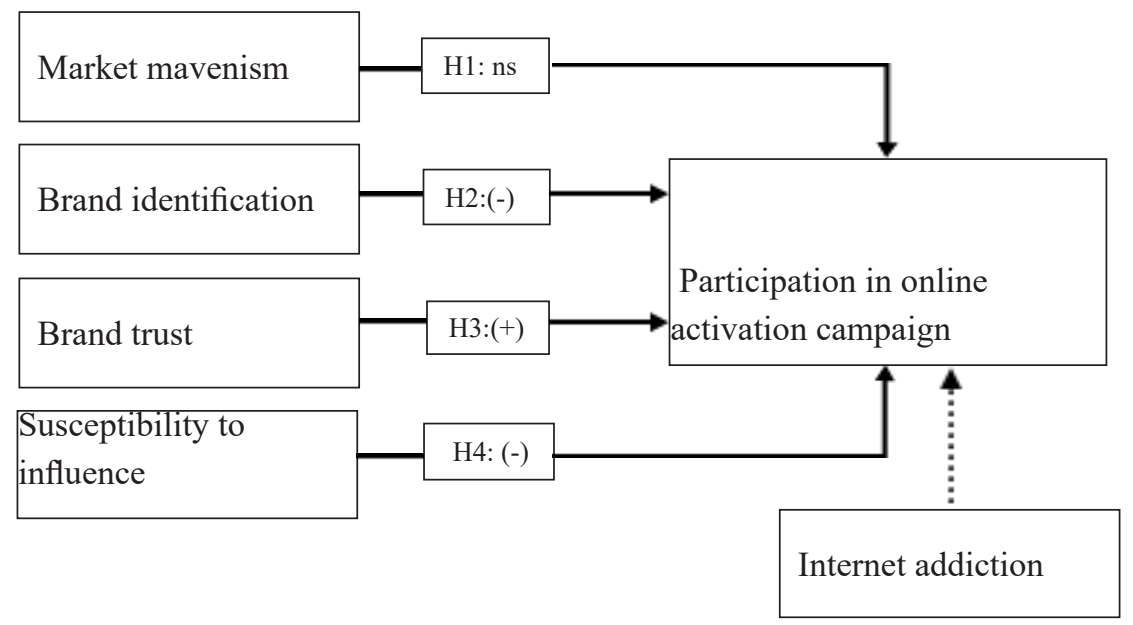

Fig. 2: Empirical model

Source: Author generated empirical model

\section{Post Hoc analysis}

To understand the surprising evidence on $\mathrm{H} 3$, we tested an alternative model to establish whether brand identification has a quadratic relationship with participation. This is due to the untested possibility that it is only persons mildly identified with brands that may seek to boost their association with it, by giving public expression to it. Accordingly, we included the squared term of brand identification and re-estimated the logistic regression model. 
Table 4: Results of post hoc analysis

\begin{tabular}{|c|c|c|c|c|}
\hline Predictors & B & Sig. & $\operatorname{Exp}(B)$ & Results \\
\hline Market mavenism & -.355 & .131 & .701 & \\
\hline Brand identification & .061 & .947 & 1.063 & \\
\hline Brand trust & .683 & .008 & 1.980 & \\
\hline $\begin{array}{l}\text { Susceptibility to } \\
\text { influence }\end{array}$ & -.738 & .016 & .478 & \\
\hline $\begin{array}{l}\text { Internet } \quad \text { addiction } \\
\text { (control) }\end{array}$ & -1.171 & .000 & .310 & \\
\hline Brand identification $^{2}$ & -.102 & .534 & .903 & \\
\hline Constant & 7.797 & .000 & 2432.494 & \\
\hline \multicolumn{5}{|c|}{$\begin{array}{l}\text { Predicted variable: Participation in online activation campaign } \\
\text { Model statistics: Homer and Lemeshow goodness of fit chi Square } \\
X^{2}=4.87, d f=8 ; \mathrm{p}=.77 \quad \text { Nagelkerke } \mathrm{R}^{2} \text { (variance explained) }=39 \% \\
\text { Correctly classified cases: } 90 \%\end{array}$} \\
\hline
\end{tabular}

Source: field data

Findings show an inferior model $\left(X^{2}=7.62 ; d f=8, p=.47\right.$; Nagelkerke R2 (variance explained) $=39 \%$; classified cases: $90 \%$ ) in which the $X 2$ is higher and the p-value is lower than those of the hypothesized model, suggesting a need to reject this competing model (Allison, 2013; Hosmer et al.,1997). In addition, the direction of effect remained unchanged while the strength of effect became weaker in the competing model. Together, these confirm the hypothesized model as the superior model suggesting a need to re-conceptualize the nature of the relationship between brand identification and engagement behaviours.

\section{Discussion and conclusions}

Online activations have gained recent popularity as almost every brand communication campaign includes an invitation for customers to join \#hashtag conversations, post brand selfies or merely 'like' a brand (campaign) page (Jansen et al., 2011). Arising 
out of pressure on brands to increase touch-points with increasingly fragmented and sophisticated consumers (Christopher, 1996), online activations aim to generate brand conversations among consumers, via earned media, that contribute to brand narratives and build visibility as messages go viral (Van Noort, Antheunis \& Van Reijmersdal, 2012). A common strategy in large economies, online activations like many internet-based phenomena, remain a recent novelty in developing countries where brands and civil society are increasingly deploying them to build visibility and generate interest.

Given the lacuna in empirical scholarship on the subject (in both marketing and communication literature and particularly as pertains in developing countries), this study tested a conceptual model of the drivers of consumers' uptake of online activations. Viewing participation in online activation campaigns as a form of customer engagement behaviour, the study examined the predictive power of market mavenism, brand identification, brand trust and individuals' susceptibility to influence over the participation variable. It found that persons who trust the activated brand would likely participate while those who are susceptible to interpersonal influence are less likely to do same. These findings support our expectations confirming, first, that trust is a key variable to look out for as brand communicators seek to use the online sphere to generate a viral buzz for their brands. Brands need to build consumer trust by delivering to expectation. It is only then that they can expect the ambassadorial behaviour that underlies participation in activations. As argued by Sashi (2012), it is only when customers trust brands that they can be expected to become advocates. Thus, to increase the possibility of a positive reception to their online activations, brands must first build credibility among relevant targets.

Secondly, brands seeking viral attention through online activations must first contend with customers at the receiving end of influence from their friends. As established here, individuals susceptible to interpersonal influence would likely not participate in such campaigns. We reason that this is because most online media users just scroll through information without 'sending it on' (Romero 
et al., 2010), thereby reducing the odds that susceptible persons would have been prompted by their influential friends to participate in them. To the extent that consumers trust communication by reference groups than they do commercial sources (Ha, 2002), invitations to participate in online activations would be better received when coming from online network members rather than brands (Kaanapali, Zhang \& Bilgihan, 2015). However, because fewer people within networks of susceptible persons would send such invitations to encourage participation (Romero et al. 2010), the influence on them becomes limited. With this in mind, brands initiating online activations may consider a two-step approach where influential online opinion leaders are identified and incentivized to 'spread the word' as they are more likely to impact susceptible customers (Kandampully, Zhang \& Bilgihan, 2015).

However, this may be easier said than done as the study finds that market mavenism is a weak predictor of participation in online activations. It appears that given their high profiles within online networks, mavens may, contrary to expectation, deem themselves to be too market savvy to be used as pawns in the hands of brand communicators to propagate brands. We had argued that because market mavens seek to position themselves to influence people's brand-related actions, they would see and use participation in online activations to that end (Qui et al., 2015).

Despite this logic (Sorokowska et al., 2016), we find that participation in online activations is completely oblivious to the individual's mavenist tendencies. Linked to the preceding discussion, therefore, it appears that while market mavens, as online opinion leaders may be influential in stimulating participation, they are not so easily driven to initiate that action. Perhaps, this is all the more reason why the suggestion to identify and incentivize such persons becomes critical. By incentivizing mavens to participate in online activation, brand communicators must consider the wider influence such persons generate rather than viewing their participation as an end in itself.

Finally, the study finds, contrary to expectation, that brand 
identification is a negative predictor of participation in online activations. Whereas identification is expected to aid consumers' public association with brands (e.g. via joining their online activations) (Ahearne et al., 2005), our evidence suggests the contrary. We even explored an alternative logic of a possible selfmoderation by the identification variable. We failed to find support for this logic. It is not clear why this is so. But we reckon this might be due to the internal sources of the identification variable (Tuškej, Golob \& Podnar, 2013), which might make its manifestation rather more personal than previously theorized. Might it be possible that the existence of the construct is so internally-sourced that brandidentified individuals prefer to keep personal this person-inanimate object emotion, rather than openly display it? Secondly, might there be other variables that condition the boundaries of the brand identification-participation link? We believe more research needs to attend to these issues and explore how identification is given expression within customer engagement contexts and particularly as pertains in the online space.

From the foregoing, we highlight three key contributions to the interactive marketing communication literature. While marketing communication scholars have explored the subject by studying brand communities (Brodie et al., 2013), social mediabased Word-of-Mouth (WOM) behaviours (Chu \& Kim, 2011; Van Noort, Antheunis\& Van Reijmersdal, 2012) and brand selfies (Presi et al., 2016), online activations remain a fallow area. We bridge this gap by examining the factors that drive participation in online activations and show the usefulness of factors such as mavenism, brand identification, brand trust and individuals' susceptibility to interpersonal influence.

We believe this sets the tone for both scholars and practitioners to understand the conditions under which online activations may be matched to the right target audiences to enhance the opportunities therein. Importantly, by explaining the participation variable as a form of customer engagement, we present scholars with a viable theoretical lens for understanding the construct. We further enrich 
the marketing communication scholarship by testing the model on a sample of respondents in a developing African country, Ghana. This brings to the subject invaluable evidence that illuminates our understanding of fast-paced, technology-driven evolutions in otherwise unexplored settings such as Ghana.

\section{Study limitations and future research directions}

The claims made in this study are subject to limitations which we encourage future scholars to address. First, is the cross-sectional design of the study along with the fact that the data were collected with a specific activation campaign in mind. While we view the conceptual model to be applicable to developing market contexts, the evidence used may be restrictive in its reach. For this reason, future scholars may consider expanding the data to include multiple countries and activations. Even better would be the need to track the hypothesized paths across time to identify any temporal boundary conditions. Secondly, the research model focused only on the factors driving participation in online activations without any attempt to explain the implications of such participation for other market-directed behaviours. For instance, does participation extend into brand use/trial? The growing body of literature on online activations would benefit from insights into what happens after participation in such campaigns. Importantly too, it remains to be seen whether any boundary variables shape the links between participation and its drivers, and possible outcomes. Future scholars are encouraged to explore these issues further. 


\section{References}

Ahearne, M., Bhattacharya, C. B., \& Gruen T. (2005). Antecedents and consequences of customer-company identification: expanding the role of relationship marketing. Journal of Applied Psychology, 90, 574-585.

Akinci, S., Kaynak, E., Atilgan, E., \& Aksoy Ş. (2007). Where does the logistic regression analysis stand in marketing literature? A comparison of the market positioning of prominent marketing journals. European Journal of Marketing, 41(5/6), 537-567.

Allison, P. (2013). Why I don't trust the Hosmer-Lemeshow test for logistic regression. Unpublished article on Statistical Horizons. Retrieved from https://statisticalhorizons.com/hosmer-lemeshow.

Bearden, W. O., Netemeyer, R. G., \& Teel, J. E. (1989). Measurement of consumer susceptibility to interpersonal influence. Journal of Consumer Research, 15(4), 473-481.

Berger, J. (2014). Word of mouth and interpersonal communication: A review and directions for future research. Journal of Consumer Psychology, 24 (4), 586-607.

Brodie, R. J., Ilic, A., Juric, B., \& Hollebeek,L. (2013). Consumer engagement in a virtual brand community: An exploratory analysis. Journal of Business Research, 66(1), 105-114.

Burgess, J. (2006). Vernacular creativity, cultural participation and new media literacy: photography and the Flickr network.Unpublished paper presented at Internet Research 7.0, Internet Convergences, Brisbane. Retrieved fromhttp://eprints.qut.edu.au/7828/1/7828.pdf.

Chaudhuri, A., \& Holbrook, M. B. (2001). The chain of effects from brand trust and brand affect to brand performance: the role of brand loyalty. Journal of Marketing, 65(2), 81-93.

Cheng, R., \& Vassileva. J. (2006). Design and evaluation of an adaptive incentive mechanism for sustained educational online communities. User Modeling and User-Adapted Interaction, 16(3), 321-348.

Christopher, M. (1996). From brand values to customer value. Journal of Marketing Practice, 2(1), 55-66.

Chu, S. C., \& Kim,Y. (2011). Determinants of consumer engagement in electronic word-of-mouth (eWOM) in social networking sites. International Journal of Advertising, 30(1), 47-75.

Cision PR Newswire (2014). Grey and the World Wildlife Fund use Snapchat to raise awareness of endangered animals. Retrieved from https:// www.prnewswire.com/news-releases/grey-and-the-world-wildlifefund-use-snapchat-to-raise-awareness-of-endangered-animals255662491.html.

CloseUpGhana (2017). Do you have any Closeup glow up moments you want to share? Retrieved from https://www.instagram.com/p/ BdTCGmyHK4V/. 
Cova, B., \& Pace, S. (2006). Brand community of convenience products: new forms of customer empowerment: The case 'My Nutella the Community”. European Journal of Marketing, 40(9/10), 1087-1105.

Dijkmans, C., Kerkhof, P., Buyukcan-Tetik, A., \& Beukeboom, C. J. (2015). Online conversation and corporate reputation: A two-wave longitudinal study on the effects of exposure to the social media activities of a highly interactive company. Journal of ComputerMediated Communication, 20(6), 632-648.

Eagar, T., Eagar, T., Dann,S., \& Dann,S. (2016). Classifying the narrated\# selfie: genre typing human-branding activity. European Journal of Marketing, 50(9/10), 1835-1857.

Feick, L. F., \& Price, L. L. (1987). The market maven: A diffuser of marketplace information. The Journal of Marketing, 51(1), 83-97.

Financial Times. (2015). Snapchat to launch sponsored selfies. Retrieved from https://www.ft.com/content/4e2f193c-6860-11e5-97d0-1456a776a4f5.

Ghana Web (2017). Citi FM launches 'Stop Galamsey Now' campaign. Retrieved from https://www.ghanaweb.com/GhanaHomePage/ NewsArchive/Citi-FM-launches-Stop-Galamsey-Now-campaign524890.

Ha, H. Y. (2002). The effects of consumer risk perception on pre-purchase information in online auctions: Brand, word-of-mouth, and customized information. Journal of Computer-Mediated Communication, 8(1), DOI: 10.1111/j.1083-6101.2002.tb00160.x.

Hollebeek, L. D. (2011). Demystifying customer brand engagement: Exploring the loyalty nexus. Journal of Marketing Management, 27(7-8), 785807.

Hollebeek, L. D., Glynn, M. S., \& Brodie,R. J. (2014). Consumer brand engagement in social media: Conceptualization, scale development and validation. Journal of Interactive Marketing, 28(2), 149-165.

Hosmer, D. W., Hosmer, T., Le Cessie, S., \& Lemeshow,S. (1997). A comparison of goodness-of-fit tests for the logistic regression model. Statistics in Medicine, 16(9), 965-980.

Islam, J. U., Rahman, Z. \& Hollebeek, L. D. (2017). Personality factors as predictors of online consumer engagement: an empirical investigation. Marketing Intelligence and Planning, 35(4), 510-528.

Jansen, B. J., Sobel, K. \& Cook, G. (2011). Classifying ecommerce information sharing behaviour by youths on social networking sites. Journal of Information Science, 37(2), 120-136.

Kandampully, J., Zhang, T. \& Bilgihan, A. (2015). Customer loyalty: a review and future directions with a special focus on the hospitality industry. International Journal of Contemporary Hospitality Management, 27(3), 379-414.

Katsikeas, C. S., Skarmeas,D. \& Bello,D. C. (2009). Developing successful trust-based international exchange relationships. Journal of International Business Studies, 40(1), 132-155. 
Kedzior, R., Allen, D. E. \& Schroeder, J. (2016). The selfie phenomenonconsumer identities in the social media marketplace. European Journal of Marketing, 50(9/10), 1767-1772.

Kitchen, P. J., Kerr, G., Schultz, D. E., McColl, R., \& Pals, H. (2014). The elaboration likelihood model: review, critique and research agenda. European Journal of Marketing, 48(11/12), 2033-2050.

Krämer, N. C., \& Winter,S. (2008). Impression management 2.0: The relationship of self-esteem, extraversion, self-efficacy, and self-presentation within social networking sites. Journal of Media Psychology, 20(3), 106-116.

Labrecque, L. I. (2014). Fostering consumer-brand relationships in social media environments: The role of parasocial interaction. Journal of Interactive Marketing, 28(2), 134-148.

Labrecque, L. I., Markos, E. \& Milne, G. R. (2011). Online personal branding: processes, challenges, and implications. Journal of Interactive Marketing, 25(1), 37-50.

Mancuso, J.,\& Stuth,K. (2014). Storytelling and marketing: The perfect pairing. Marketing Insights. Retrieved from https://www.ama.org/ publications/MarketingInsights/Pages/storytelling-and-marketing-theperfect-pairing.aspx.

Maslowska, E., Malthouse, E. C. \& Collinger, T. (2016). The customer engagement ecosystem. Journal of Marketing Management, 32(5-6), 469-501.

Morgan, R. M.,\& Hunt. S. D. (1994). The commitment-trust theory of relationship marketing. Journal of Marketing, 58(3), 20-23

MTN Ghana (2017). It's a Ghana thing. Radio advert cited on CitiFM in Febrary 2017.

Opoku, R., Abratt, R. \& Pitt, L. (2006). Communicating brand personality: Are the websites doing the talking for the top South African Business Schools? Journal of Brand Management, 14(1/2), 20-39.

Opoku, O. M. \& Kuranchie, A. (2015). Examination of stakeholders' awareness and preparedness for on-line learning in Ghana. Mediterranean Journal of Social Sciences, 6(6), 469-476.

Owusu-Acheaw, M., \& Larson, A. G. (2015). Use of social media and its impact on academic performance of tertiary institution students: A study of students of Koforidua Polytechnic, Ghana. Journal of Education and Practice, 6(6), 94-101.

Packard, G., \& Wooten, D. B. (2013). Compensatory knowledge signaling in consumer word-of-mouth. Journal of Consumer Psychology, 23(4), 434-450.

Paul, K. (2015). Stakeholder theory, meet communications theory: Media systems dependency and community infrastructure theory, with an application to California's cannabis/marijuana industry. Journal of Business Ethics, 129(3), 705-720. 
Presi, C., Maehle, N., \& Kleppe, I. A. (2016). Online activation campaigns: consumer experiences and marketplace conversations. European Journal of Marketing, 50(9/10), 1814-1834.

Romero, D. M., Galuba, W., Asur, S., \& Huberman, B. A. (2011). Influence and passivity in social media. Proceedings of the 20th international conference companion on World Wide Web, 113-114.

Saltz, J. (2014). Art at arm's length: A history of the selfie. New York Magazine, 47(2), 71-75.

Sashi, C. M. (2012). Customer engagement, buyer-seller relationships, and social media. Management Decision, 50(2), 253-272.

Schroeder, J.E.,\& Salzer-Morling, M. (2006).Brand culture. London: Routledge

Sheth, J. N. (2011). Impact of emerging markets on marketing: Rethinking existing perspectives and practices. Journal of Marketing, 75(4), 166182.

Sorokowska, A., Oleszkiewicz, A., Frackowiak, T., Pisanski, K., Chmiel, A., \& Sorokowski,P. (2016). Selfies and personality: Who posts self-portrait photographs? Personality and Individual Differences, 90, 119-123.

Spencer, J. W. (2008). The impact of multinational enterprise strategy on indigenous enterprises: Horizontal spillovers and crowding out in developing countries. Academy of Management Review, 33(2), 341361 .

Stokburger-Sauer, N., Ratneshwar, S., \& Sen, S. (2012). Drivers of consumerbrand identification. International Journal of Research in Marketing, 29(4), 406-418.

Sudbury-Riley, L. (2016). The baby boomer market maven in the United Kingdom: an experienced diffuser of marketplace information. Journal of Marketing Management. Retrieved from DOI: 10.1080/0267257X.2015.1129985.

Sung, Y., Lee, J. A., Choi, S. M., \& Kim, E. (2016). \# Me and brand: understanding the brand-selfie posters on social media. International Journal of Advertising. Retrieved from https://doi.org/10.1080/026504 87.2017.1368859

Tuškej, U., Golob, U. \& Podnar, K. (2013). The role of consumer-brand identification in building brand relationships. Journal of Business Research, 66(1), 53-59.

Van Doorn, J., Lemon, K. N., Mittal, V., Nass, S., Pick, D., Pirner, P., \& Verhoef, P. C. (2010). Customer engagement behaviour: Theoretical foundations and research directions. Journal of Service Research, 13(3), 253-266.

Van Noort, G., Antheunis, M. L. \&Van Reijmersdal, E. A. (2012). Social connections and the persuasiveness of viral campaigns in social network sites: Persuasive intent as the underlying mechanism. Journal of Marketing Communications, 18(1), 39-53. 
Van Varik, F. J. M., \& Van Oostendorp, H. (2013). Enhancing online community activity: development and validation of the CA framework. Journal of Computer-Mediated Communication, 18(4), 454-475.

Wang, A. (2006). When synergy in marketing communication online enhances audience response: The effects of varying advertising and product publicity messages. Journal of Advertising Research, 46(2), 160-170.

Wang, X., Yu,C. \& Wei.Y. (2012). Social media peer communication and impacts on purchase intentions: A consumer socialization framework. Journal of Interactive Marketing, 26(4), 198-208.

Whang, L. S. M., Lee, S., \& Chang, G. (2003). Internet over-users' psychological profiles: a behaviour sampling analysis on internet addiction. Cyber Psychology and Behaviour, 6(2),143-150.

Willens, M. (2014). \#Soloselfie goes viral for beats in a week when repeats ruled. AdAge. Retrieved from http://adage.com/article/the-viralvideo-chart/soloselfie-viral-beats/296042/.

World Bank. (2014). Internet Users (per 100 people). Retrieved from http:// data.worldbank.org/indicator/IT.NET.USER.P2?view=map

Zeriti, A., Robson, M. J., Spyropoulou, S. \& Leonidou. C. N. (2014).

Sustainable export marketing strategy fit and performance. Journal of International Marketing, 22(4), 44-66. 